\title{
Milk Yield and Composition and Pasture Ruminal Digestion in Grazing Dairy Cows Receiving Three Levels of Energy Concentrate Supplementation
}

\section{Eloy Eduardo Salado ${ }^{1}$, Gustavo Bretschneider ${ }^{2}$, Alejandra Cuatrin1ㅜ, Adriana María Descalzo ${ }^{3}$, Gerardo Antonio Gagliostro ${ }^{4}$}

\footnotetext{
${ }^{1}$ Area de Investigación en Producción Animal, Instituto Nacional de Tecnología Agropecuaria, Rafaela, Argentina

${ }^{2}$ Agencia de Extensión Rural Necochea, Instituto Nacional de Tecnología Agropecuaria, Necochea, Argentina ${ }^{3}$ LABINTEX-EUROPA-INTAPersyst, UMR QUALISUD-Bâtiment 16-Bureau 340, Montpellier, France

${ }^{4}$ Area de Investigación en Producción Animal, Instituto Nacional de Tecnología Agropecuaria, Balcarce, Argentina

Email: *salado.eloy@inta.gob.ar
}

How to cite this paper: Salado, E.E., Bretschneider, G., Cuatrin, A., Descalzo, A.M. and Gagliostro, G.A. (2017) Milk Yield and Composition and Pasture Ruminal Digestion in Grazing Dairy Cows Receiving Three Levels of Energy Concentrate Supplementation. Agricultural Sciences, 8, 1135-1156. https://doi.org/10.4236/as.2017.810083

Received: September 18, 2017

Accepted: October 22, 2017

Published: October 25, 2017

Copyright $\odot 2017$ by authors and Scientific Research Publishing Inc. This work is licensed under the Creative Commons Attribution International License (CC BY 4.0).

http://creativecommons.org/licenses/by/4.0/

\section{Open Access}

\begin{abstract}
The objective of the experiment was to determine the effect of feeding three levels (T3.5, T7.0 and T10.5) of energy concentrate (3.5, 7.0 and $10.5 \mathrm{~kg} \mathrm{cow}^{-1}$ day $^{-1}$ ) on total dry matter (DM) and energy intakes, milk yield and composition, nutritional value of milk and rumen pasture neutral detergent fiber (NDF) digestion in grazing dairy cows. Twenty-one multiparous Holstein cows in early lactation $(70.2 \pm 13$ days postpartum) producing $37.1( \pm 4.7) \mathrm{kg}$ of milk were assigned to a 3 treatments $(7$ cows/treatment $) \times 3$ periods Latin square design. Parameters of ruminal environment and pasture NDF degradation were obtained using 3 additional cows of the same breed fitted with rumen cannulae. On a wet basis, concentrate was composed by corn grain (68\%), soybean meal (22\%), wheat bran ( $8 \%)$ and a vitamin-mineral nucleus with monensin. Pasture (Medicago sativa, sp) was used in a rotational grazing system with an herbage allowance of $30 \mathrm{~kg} \mathrm{DM} \mathrm{cow}^{-1} \mathrm{~d}^{-1}$. Yield $\left(\mathrm{kg} \mathrm{cow}^{-1} \mathrm{~d}^{-1}\right)$ of fat corrected milk $(4 \%$ FCM) resulted higher $(p<0.05)$ in T7.0 $(29.0)$ compared to T3.5 (26.8) but similar to T10.5 (30.2). Milk and protein yields were linearly increased $(p<0.01)$ by concentrate intake. Milk fat $(3.13 \mathrm{~g} / 100 \mathrm{~g})$ and total solid contents $(11.79 \mathrm{~g} / 100 \mathrm{~g})$ did not differ whereas milk protein $(p<$ $0.03)$ and casein $(p<0.01)$ levels $(\mathrm{g} / 100 \mathrm{~g})$ increased linearly from 3.05 to 3.10 (protein) and from 2.42 to 2.47 (casein). Pasture intake decreased but total DM and energy consumption were enhanced showing addition effects after concentrate feeding. Body weight (BW) loss and plasmatic levels of non esterified
\end{abstract}


fatty acids (NEFA) decreased with concentrate intake. Circulating levels of insulin-like growth factor-I (IGF-I) were higher $(p<0.05)$ in T10.5 while those of glucose, plasma urea nitrogen, insulin and somatotrophin were not affected. Ruminal $\mathrm{pH}$ and acetate concentration resulted lower $(p<0.05)$ in T10.5 when compared to T3.5. The acetate:propionate ratio decreased ( $p<$ 0.01 ) from 4.25 in T3.5 to 3.08 in T10.5 and ruminal ammonia nitrogen levels tended $(p<0.07)$ to be lower as concentrate intake increased. Kinetics parameters of NDF degradation remained unchanged. The potential hypercholesterolemic fatty acids (FA) of milk (C12:0 to C16:0.) remained unchanged as concentrate intake increased. Milk content of linolenic acid decreased and the $\mathrm{n}-6: \mathrm{n}-3$ ratio increased with concentrate intake from 1.56 (T3.5) to 2.57 (T10.5) remaining below the recommended values for human health $(<4: 1)$. Milk content of antioxidant vitamins was not significantly altered even when pasture DM intake fall in T10.5 compared to T3.5. Increased consumption of a starch-rich concentrate up to $40 \%$ of DM intake of cows showed additive effects on total DM and energy intakes improving milk yield, milk protein and casein contents without negative effects on milk fat concentration or yield. Pasture fiber digestion and nutritional parameters linked to healthy value of milk fat were not affected.

\section{Keywords}

Grazing Dairy Cows, Milk Yield, Concentrate Supplementation, Rumen Digestion

\section{Introduction}

Significant variability in commodity prices and perceived animal welfare concerns around permanent housing of livestock have led to increased global interest in grazing production systems for dairy cows [1]. The last trends in sustainable production practices encourage the use of pasture based systems for milk production but the functionality of biologically complex processes like rumen digestion, supplementation and pasture production needs to provide new knowledge necessary to underpin practical development of those systems [2]. High-quality pastures are the most economical feed for dairy cattle and contribute to lowering the cost of milk production [3] but their energy density is insufficient for high-yielding cows to achieve their maximum production potential [4]. A lower DM and hence energy intake explains the suboptimal performance observed even under conditions of adequate quality and quantity of forage [5]. Maximizing pasture intake implies offering high amounts $\left(60 \mathrm{~kg} \mathrm{DM} \mathrm{cow}^{-1} \mathrm{day}^{-1}\right)$ of forage measured at ground level resulting in a low harvest efficiency and a progressive deterioration in pasture quality [6]. According to [7], the maximum pasture intake would be equivalent to $3.2 \%$ of BW whereas the potential consumption of cows supplemented with concentrates is near to $4 \%$ of BW [8]. 
When spring pasture is the sole feed supplied maximum yield of milk is expected to be near to $23.2 \mathrm{~kg} \mathrm{cow}^{-1} \mathrm{day}^{-1}$ [9] and for larger milk production body energy mobilization is needed increasing the risk of metabolic and reproductive disorders [10]. In this context, supplementary energy may improve the productive response of cows [11] reducing body reserves losses [12].

Energy to protein imbalances in pasture-based diets may in turn be attenuated by increased consumption of starch-rich concentrates [13]. However, feeding large amounts of cereal based concentrates in the milking parlor may affect ruminal $\mathrm{pH}$ and pasture NDF digestion [14], with concomitant decreases in forage intake and milk fat content. On the other hand, feeding diets with reduced pasture content may affect the nutrition (healthy) value of milk by lower levels of rumenic acid (9-cis 11-trans $\left.\mathrm{C}_{18: 2}, \mathrm{RA}\right), \alpha$-linolenic acid $\left(\mathrm{C}_{18: 3 n-3}\right)$ and antioxidant vitamins [15]. The objective of the experiment was to determine the effect of three levels of energy concentrate intake on production, composition and nutritional value of milk, DM and energy intake and rumen digestion in grazing dairy cows.

\section{Materials and Methods}

\subsection{Cows and Treatments}

The experiment was carried out in the experimental farm of INTA Rafaela $\left(31^{\circ} 12^{\prime} \mathrm{S}, 61^{\circ} 30^{\prime} \mathrm{W}\right)$ during the spring of 2009 . Measurements of milk production and composition, BW, body condition score (BCS), DM intake (DMI) and plasma metabolite and hormone concentration were carried out using 21 multiparous (3.3 \pm 1.7 lactations) Holstein cows in early lactation (70.2 \pm 13 days postpartum). At the start of the trial, cows produced $37.1( \pm 4.7) \mathrm{kg}$ milk, averaging $593( \pm 59.9)$ BW and $2.52( \pm 0.24)$ BCS. Cows were grouped by milk production, number of lactations and days postpartum and randomly assigned to 3 treatments ( 7 cows/treatment) according to a Latin square design with 3 experimental periods of 19 days long (14 days for adaptation and 5 for data collection). Parameters of ruminal environment and digestion were obtained using 3 cows of the same breed fitted with rumen cannulae in a Latin square design with experimental periods of 19 days (17 days for adaptation and 2 of measurements). All cows were fitted with transponders (ALPRO version 6.60/DeLaval, Tumba, Sweden) to individually record daily milk production and concentrate allocation in the milking parlor. Treatments were three levels (T3.5, T7.0 and T10.5) of concentrate intake (3.5, 7.0 and $10.5 \mathrm{~kg} \mathrm{cow}^{-1}$ day $^{-1}$ ) composed (wet basis) of corn grain $(68 \%)$, soybean meal $(22 \%)$, wheat bran $(8 \%)$ and a vitamin-mineral nucleus with monensin. It was supplied by halves in individual feeders during each milking time (4:30 a.m. and 3:30 p.m.). An alfalfa (Medicago sativa, sp) pasture was used in a rotational grazing system with an herbage allowance of 30 $\mathrm{kg} D M \operatorname{cow}^{-1} \mathrm{~d}^{-1}$ adjusted using portable electric wiring. During the 3 weeks prior to the start of the trial all cows received $7.0 \mathrm{~kg}$ of the experimental concentrate and pasture. 


\subsection{Samples Collection and Analysis}

Herbage mass $\left(\mathrm{kg} \mathrm{DM} \mathrm{ha}^{-1}\right)$ was weekly measured by cutting samples at $4 \mathrm{~cm}$ in height [16]. Samples of concentrate and pasture were obtained by hand-plucking [17] during the last 5 days of each experimental period. All samples were dried $\left(65^{\circ} \mathrm{C}\right.$ for $48 \mathrm{~h}$ ) and ground through a 1-mm screen (Wiley mill, Philadelphia, PA). Two representative composite samples from each experimental period were analyzed for content of NDF (aNDF; assayed with sodium sulfite, with a heat stable alpha amylase and expressed inclusive of residual ash) [18], FDA (expressed inclusive of residual ash) ([19]; procedure 973.18), ether extract ([20]; procedure 920.39], acid detergent lignin ([19]; procedure 973.18), total nitrogen (Kjeldhal method 976.05 of [20]), CP (total nitrogen $\times 6.25$ ), ash ([19]; procedure 942.05) and DM in vitro digestibility (IVDMD) according to [21]. Nonfibrous carbohydrates content (NFC, \%) was calculated using the equation: 100 (\% aNDF $+\% \mathrm{~PB}+\% \mathrm{EE}+\%$ ash) [22]. Concentrate samples were also analyzed for starch content [23].

Milk production was individually recorded over the last 5 days of each experimental period by a DeLaval ALPRO milk metering system (DeLaval International AB, Tumba, Sweden). Individual milk samples were collected at days $15^{\text {th }}$ and $18^{\text {th }}$ of each period, composited according to the corresponding volume measured at each milking time and analyzed for content of fat, total protein, lactose, total solids (TS), non-fat solids (NFS) and urea by infrared spectrophotometry (MilkoScan ${ }^{\mathrm{TM}}$ Minor; FOSS Electric, Hillerod, Denmark) according ISO/IDF standard method [24]. Milk casein content was calculated as 6.38 * (total $\mathrm{N}$ - non caseinic N) after semi Micro-Kjeldhal digestion. Fat-corrected milk (4\% FCM) was adjusted according to [25] and energy-corrected milk (ECM) as proposed by [26]. In each experimental period an additional sample of milk (pool per treatment) was stored at $-24^{\circ} \mathrm{C}$ for determination of milk FA composition and antioxidant compounds. The lipids were extracted [27] and after basic methylation with solution of sodium methoxide (1\%) on anhydrous methanol injected into a gas chromatograph (Perkin-Elmer, model Autosystem XL-R 3.5) fitted with a PSS injector (Programmed Temperature Vaporizer), flow divider and flame ionization detector (FID). The methyl esters of FA were separated on a WCOT fused silica capillary column, $200 \mathrm{~m} \times 0.25 \mathrm{~mm}$ i.d. (Varian), using $\mathrm{H}_{2}$ as the carrier gas. The individual FA were identified by comparing the relative retention times with pure standards (Mix of 37 components (AccuStandard), PUFA-2 Animal Source (Supelco, Bellefonte, PA, USA) and a mixture of isomers of methyl esters linoleic acid (Supelco)). Analytical results were expressed as percentages of total FA. Antioxidant vitamins ( $\alpha$ - $\gamma$-tocopherol, $\beta$-carotene and retinol) were analyzed by extraction with saponification in hexane and subsequent separation and quantification using reverse phase HPLC methodology with detection at $445 \mathrm{~nm}$ for carotenes and fluorescence at 296-330 nm for tocopherols as described in [28]. The quantification was based on calibration curves performed with commercial standards of each compound (Sigma-Aldrich, Argentina). 
Concentrate intake was determined throughout the trial by the difference between offered and refused material. Pasture intake was estimated in each experimental period from the individual production of faeces and the in vitro DM digestibility (IVDMD) of the pasture. The total faecal production of each cow was determined using an indigestible marker (LIPE ${ }^{\circledR}$ ) according to [29]. The cows were dosed once a day $(11: 30 \mathrm{~h})$ with a gelatin capsule containing $500 \mathrm{mg}$ of LIPE ${ }^{\circledR}$ for 7 consecutive days, starting on Day 1 and finishing on Day 7. Animals were restrained in a head bail and capsules were inserted into the esophagus utilising a balling gun. Concentrations of LIPE $^{\circledR}$ reach equilibrium in faeces approximately 48 hours after initial dosage. Therefore, faecal samples were taken from the rectum of each cow once a day $(11: 30 \mathrm{~h})$ for five consecutive days, from Day 4 of LIPE ${ }^{\circledR}$ dosage until Day 8. All faecal samples were processed and analyzed individually. Faecal samples were weighed and dried immediately after sampling at $60^{\circ} \mathrm{C}$ in a forced air oven until constant weight to determine DM content. Samples were ground through a 1-mm screen (Wiley mill, Philadelphia, PA) and stored for analysis. DM was also determined using an oven at $105^{\circ} \mathrm{C}$ until constant weight. Two $\mathrm{mg}$ of faecal sample and $300 \mathrm{mg}$ of powdered Potassium bromide $(\mathrm{KBr})$ were ground in an agate mortar and homogenised for 20 minutes. Pressed pellets were then obtained after 1 minute at constant pressure. Concentration of LIPE ${ }^{\circledR}$ in faeces was analysed by infrared spectroscopy using an infrared spectrometer VARIAN 800 FT-IR (Varian BV, Middelburg, and The Netherlands). Standard calibration curves for LIPE ${ }^{\circledR}$ were prepared by measuring the absorbance of five different concentrations of LIPE $^{\circledR}$ in faeces to produce a regression equation relating concentration to absorbance, which had an R2 higher than 0.95 . This equation allowed calculations of LIPE $^{\circledR}$ concentration by measuring absorbance in faecal samples. Total faecal DM output was estimated based on the ratio of the amount of marker administered to marker concentration in faeces (Total faecal output $\left(\mathrm{g} \mathrm{DM}\right.$ day $\left.^{-1}\right)=$ Dosed intake marker ( $\mathrm{g}$ day $\left.^{-1}\right) /$ Marker concentration in faeces $\left(\mathrm{g} \mathrm{g} \mathrm{DM}\right.$ at $\left.105^{\circ} \mathrm{C}^{-1}\right)$ ). The recovery rate for $\operatorname{LIPE}^{\circledR}$ was assumed to be $100 \%$ [29]. Faecal DM output due to concentrate was estimated as concentrate intake $\times(1-$ concentrate IVDMD $)$. This quantity was subtracted from the total faecal DM output and the remaining faecal DM material was attributed to pasture. Pasture DMI was calculated as the ratio between faecal DM output due to pasture and pasture indigestibility (1 - IVDMD). Total energy intake was calculated from DMI of forage and concentrates and their $\mathrm{NE}_{\mathrm{L}}$ content estimated according to [22]. Glucogenic energy intake was calculated as proposed in [30] assuming that intestinal digestibility for starch was $78 \%$ [31].

Cows were weighed after the morning milking at the beginning and end of each experimental period avoiding previous access to water. Concurrently, BCS was determined as the average records of two independent observers using a 5 -point scale ( 1 = excessively thin to $5=$ excessively fat $)$ with increments of 0.25 
units [32]. On the last day of each experimental period and after the morning milking, blood samples were taken by coccygeal vein puncture. Blood was collected in tubes containing sodium heparin $(5 \mathrm{U} / \mathrm{ml})$ and plasma was obtained by centrifugation $\left(2000 \times \mathrm{g}\right.$ at $4^{\circ} \mathrm{C}$ for $\left.15 \mathrm{~min}\right)$ and stored frozen $\left(-24^{\circ} \mathrm{C}\right)$ until glucose, urea, NEFA, insulin, GH and IGF-I analysis as described in [33].

\subsection{Rumen Environment and in Situ Pasture NDF Degradability}

The rate and extent of pasture NDF degradation was estimated using the in situ technique [34]. At the beginning of the incubation period, two bags containing 5 g DM of pasture per sampling hour were introduced into the ventral sac of the rumen of the cannulated cows. The bags were extracted by duplicate for the different hours of incubation $(0,4,8,12,16,20,24,36$ and 48 hours) and frozen $\left(-24^{\circ} \mathrm{C}\right)$ until the end of each period. Afterwards, they were thawed and externally washed under a cold water stream to remove contaminating and soluble material. Then all the bags were washed in a washing machine, dried in a forcedair oven $\left(60^{\circ} \mathrm{C}\right.$ for 48 hours) and weighed to determine the residual $\mathrm{DM}$ and NDF contents.

Kinetics parameters of NDF degradation were estimated with the equation proposed by [35] using the Excel solver routine [36]: $R=D^{*} \mathrm{e}^{-\left(k^{*}(t-L)\right)}+U$, where $R=$ NDF residue (at time after incubation $=t$ ), $D=$ digestible fraction, $k$ = digestion rate constant, $L=$ lag time, and $U=$ indigestible fraction. The effective degradation of NDF was calculated as: $(D / 100) *(k /(k+k p)) * \mathrm{e}^{-((k p / 100) * L)}$ assuming a $\mathrm{kp}$ value of $5 \% \mathrm{hour}^{-1}$ [37].

During the first six sampling hours, $200 \mathrm{~mL}$ of ruminal liquor (ventral sac) were drawn from each cannulated cow for measurements of $\mathrm{pH}$, ammonia nitrogen $\left(\mathrm{NH}_{3}-\mathrm{N}\right)$ and volatile fatty acid (VFA). Immediately after extraction and previous filtration of the ruminal liquor with cheese-like cloth, $\mathrm{pH}$ was measured with a portable digital $\mathrm{pH}$-meter (ORION model $250 \mathrm{~A}$ ). A sample $(100 \mathrm{~mL})$ was acidified with $1 \mathrm{~mL}$ of $1 \mathrm{~N} \mathrm{H}_{2} \mathrm{SO}_{4}$ and stored at $-20^{\circ} \mathrm{C}$ until the $\mathrm{NH}_{3}-\mathrm{N}$ and VFA determinations. The $\mathrm{NH}_{3}-\mathrm{N}$ concentration was determined by titration with steam entrainment, prior to alkalization of the samples with sodium hydroxide. For VFA determination, the samples were purified with orthophosphoric acid (25\%) on sulfuric acid $0.5 \mathrm{M}$ at $0.5 \mathrm{~mL}$ for each $2 \mathrm{~mL}$ of sample and then centrifuged per $10 \mathrm{~min}$ with $5000 \mathrm{~g}$ [38]. Samples were injected by auto-sampler Robokrom ${ }^{\circledR}$ GC on a Konik GC 5000 B equipped with a flame ionization detector. VFA (injected using a 10:1 split ratio and splitless time 9) were separated on a Nukol capillary column $(30 \mathrm{~m} \times 0.32 \mathrm{~mm}$ i.d. $\times 0.25 \mu \mathrm{m}$ film thickness; Perkin Elmer - Elite FFAP; Part. N9316354). The FID injector temperature was held at $250^{\circ} \mathrm{C}$, and the detector temperature at $250^{\circ} \mathrm{C}$. The initial oven temperature was $80^{\circ} \mathrm{C}$ (held for $1 \mathrm{~min}$ ), which was then increased to $156^{\circ} \mathrm{C}$ at a rate of $9^{\circ} \mathrm{C} / \mathrm{min}$ (held for $0 \mathrm{~min}$ ). Hydrogen $\left(\mathrm{H}_{2}\right)$ was used as a carrier gas and column flow was held at $2.4 \mathrm{~mL} / \mathrm{min}$. It was used for the calibration curves the standard volatile acid mix Supelco (Cat. No. 46975-U). 


\subsection{Statistical Analysis}

Milk production and composition, changes in BW and BCS, DM intake, plasma metabolite and hormone concentration and kinetics parameters of NDF degradation were analyzed in a $3 \times 3$ Latin-square design with the MIXED procedure of SAS [39] using the following model: $Y_{i j k l}=\mu+T_{i}+P_{j}+S_{k}+A_{(k) l}+E_{i j k l}$, where $\mathrm{Y}_{\mathrm{ijkl}}=$ dependent variable; $\mu=$ overall mean; $T_{i}=$ treatment effects; $P_{j}=$ effects of the experimental period; $S_{k}=$ effects of the sequence; $A_{(k) l}=$ random effects of animal within sequence and $E_{i j k l}=$ residual error. The rumen parameters $(\mathrm{pH}$, $\mathrm{NH}_{3}-\mathrm{N}$ and VFA) were analyzed in a $3 \times 3$ Latin-square design using the following model: $Y_{i j k l m}=\mu+T_{i}+P_{j}+S_{k}+A_{(k) l}+H_{m}+(T \times H)_{i m}+E_{i j k l m}$, where $Y_{i j k l m}$ = dependent variable; $\mu$ overall mean; $T_{i}=$ treatment effects; $P_{j}=$ effects of the experimental period; $S_{k}=$ effects of the sequence; $A_{(k) l}=$ random effects of animal within sequence, $H_{m}=$ effects of hour of sampling; $(T \times H)_{i m}$ = interaction effects of treatment and hour and $E_{i j k l m}=$ residual error. Mean comparisons were carried out using the Tukey-Kramer test, and differences were considered significant with $p<0.05$. Linear and/or quadratic effects of concentrate levels were also tested by orthogonal contrasts.

\section{Results}

\subsection{Chemical Composition of Feedstuffs}

The average value of herbage mass in the pregrazing strips was $1996( \pm 260) \mathrm{kg}$ $\mathrm{DM} \mathrm{ha} \mathrm{h}^{-1}$ and the average herbage allowance obtained was $31.4( \pm 1.9) \mathrm{kg} \mathrm{DM}$ $\mathrm{cow}^{-1}$ per day during the trial. Values for the chemical composition of the feedstuffs used in this trial are shown in Table 1.

Pasture DM content was above the critical range $(15 \%-18 \%)$ that would

Table 1. Chemical composition of pasture and experimental concentrate. ${ }^{1}$

\begin{tabular}{ccc}
\hline Parameters & Pasture $^{2}$ & Concentrate \\
\hline DM (\%) & $22.5 \pm 2.0$ & $90.8 \pm 1.0$ \\
g/100g DM & \\
OM & $90.2 \pm 0.8$ & $93.9 \pm 0.8$ \\
IVDMD & $75.2 \pm 2.8$ & $86.1 \pm 3.5$ \\
CP & $25.1 \pm 3.3$ & $18.3 \pm 2.0$ \\
NDF & $34.8 \pm 3.9$ & $18.0 \pm 2.0$ \\
ADF & $19.9 \pm 1.6$ & $6.6 \pm 1.2$ \\
LDA & $4.6 \pm 1.1$ & $1.2 \pm 0.4$ \\
EE & $2.9 \pm 0.3$ & $6.0 \pm 0.6$ \\
Starch & nd & $42.5 \pm 4.4$
\end{tabular}

${ }^{1}$ Values are expressed through the mean \pm standard deviation. ${ }^{2}$ Perennial pastures of alfalfa (Medicago sativa). $\mathrm{DM}=$ dry matter; $\mathrm{OM}=$ organic matter; IVDMD = in vitro $\mathrm{DM}$ digestibility; $\mathrm{CP}=$ crude protein; $\mathrm{NDF}$ $=$ neutral detergent fiber; $\mathrm{ADF}=$ acid detergent fiber; $\mathrm{ADL}=$ acid detergent lignin; $\mathrm{EE}=$ ether extract; $\mathrm{nd}=$ not determined. 
affect voluntary DM intake [40]. The average pasture NDF content was close to the range of $34 \%$ to $36 \%$, which would not affect voluntary DMI due to rumen fill [41]. Pasture CP content was in the range of $15 \%$ to $25 \%$ proposed by [42] to obtain high values of forage DM digestibility. The maximum DM intake would be achieved when pasture allowance is about $31 \mathrm{~kg} \mathrm{DM} \mathrm{cow}^{-1} \mathrm{day}^{-1}$ measured at more than $3 \mathrm{~cm}$ above the ground level [43] a value that resulted very close to that used in this study. This value is within the range proposed by [44] who reported that the maximum DM intake would be obtained when pasture supply ranges between 45 and $55 \mathrm{~g} \mathrm{DM} \mathrm{kg} \mathrm{BW}^{-1}$ day $^{-1}$. For an average cow used in the present study this amount would be equivalent to about 26 to $32 \mathrm{~kg} \mathrm{DM} \mathrm{day}{ }^{-1}$. In alfalfa pastures under rotational grazing, maximum DM intake (19.5 kg DM $\mathrm{cow}^{-1} \mathrm{day}^{-1}$ ) of non-supplemented dairy cows was obtained when herbage allowance was $30 \mathrm{~kg} \mathrm{DM} \mathrm{cow}^{-1}$ day $^{-1}$ [45]. Furthermore, when pasture biomass averaged $2000 \mathrm{~kg} \mathrm{DM} \mathrm{ha}^{-1}$ and grazing time was not restricted maximum forage consumption was obtained [42]. In this trial, it seems that herbage allowance and forage quality were highly enough to achieve high DM and energy intakes.

\subsection{Milk Production and Composition}

ECM and 4\% FCM yields were significantly higher in T7.0 compared to T3.5 but similar to those obtained in T10.5 while milk and protein yields increased $(+13.6 \%$ and $+14.9 \%$, respectively) with level of supplementation (Table 2$)$. Milk

Table 2. Milk production and composition in grazing dairy cows supplemented with 3.5 (T3.5), 7.0 (T7.0) and 10.5 (T10.5) $\mathrm{kg} \mathrm{d}^{-1}$ of concentrate.

\begin{tabular}{|c|c|c|c|c|c|c|c|}
\hline \multirow{2}{*}{ Parameter } & \multicolumn{3}{|c|}{ Treatment $^{1}$} & \multirow{2}{*}{ SEM } & \multicolumn{3}{|c|}{$P<<^{2}$} \\
\hline & T3.5 & T7.0 & $\mathrm{T} 10.5$ & & Treat $^{2}$ & Lineal $^{3}$ & Quadratic $^{3}$ \\
\hline Milk, $\mathrm{kg} \mathrm{d}^{-1}$ & $30.8^{\mathrm{c}}$ & $33.3^{\mathrm{b}}$ & $35.0^{\mathrm{a}}$ & 1.2 & 0.01 & 0.01 & 0.35 \\
\hline $4 \%$ FCM, $\mathrm{kg} \mathrm{d}^{-1}$ & $26.8^{\mathrm{b}}$ & $29.0^{\mathrm{a}}$ & $30.2^{\mathrm{a}}$ & 1.1 & 0.01 & 0.01 & 0.40 \\
\hline $\mathrm{ECM}, \mathrm{kg} \mathrm{d}^{-1}$ & $26.7^{\mathrm{b}}$ & $29.0^{\mathrm{a}}$ & $30.2^{\mathrm{a}}$ & 1.0 & 0.01 & 0.01 & 0.37 \\
\hline Fat, $\mathrm{kg} \mathrm{cow}^{-1} \mathrm{~d}^{-1}$ & $0.97^{\mathrm{b}}$ & $1.05^{\mathrm{ab}}$ & $1.08^{\mathrm{a}}$ & 0.04 & 0.02 & 0.01 & 0.51 \\
\hline Fat, \% & 3.15 & 3.16 & 3.09 & 0.08 & 0.79 & 0.63 & 0.64 \\
\hline Protein, $\mathrm{kg} \mathrm{cow}^{-1} \mathrm{~d}^{-1}$ & $0.94^{\mathrm{c}}$ & $1.02^{\mathrm{b}}$ & $1.08^{\mathrm{a}}$ & 0.03 & 0.01 & 0.01 & 0.35 \\
\hline Protein, \% & 3.05 & 3.08 & 3.10 & 0.04 & 0.08 & 0.03 & 0.60 \\
\hline Lactose, \% & $4.85^{\mathrm{b}}$ & $4.91^{\mathrm{a}}$ & $4.94^{\mathrm{a}}$ & 0.03 & 0.01 & 0.01 & 0.43 \\
\hline TS, \% & 11.73 & 11.84 & 11.82 & 0.11 & 0.57 & 0.42 & 0.50 \\
\hline NFS, \% & $8.58^{\mathrm{b}}$ & $8.69^{\mathrm{a}}$ & $8.74^{\mathrm{a}}$ & 0.06 & 0.01 & 0.01 & 0.34 \\
\hline Urea, \% & $0.046^{\mathrm{a}}$ & $0.045^{\mathrm{a}}$ & $0.043^{\mathrm{b}}$ & 0.001 & 0.01 & 0.01 & 0.53 \\
\hline Casein, \% & $2.42^{\mathrm{b}}$ & $2.44^{\mathrm{b}}$ & $2.47^{\mathrm{a}}$ & 0.01 & 0.01 & 0.01 & 0.62 \\
\hline
\end{tabular}

${ }^{1}$ Values are expressed as least square means (LSMeans) and standard error of LSMeans (SEM). ${ }^{2}$ Effect of treatment (Treat). ${ }^{3}$ Contrast. ${ }^{\mathrm{a}, \mathrm{b}, \mathrm{c}}$ Within rows LSMeans with different letters differs (Tukey-Kramer test, $P<$ 0.05). $4 \%$ FCM = milk fat corrected $4 \%$ ECM = milk corrected energy; $\mathrm{TS}=$ total solids; NFS = non-fat solids. 
fat yield in T10.5 resulted higher compared to T3.5 and similar to T7.0 without significant differences between T3.5 and T7.0.

Milk fat and TS contents were similar between treatments, whereas protein content tended $(p<0.08)$ to be higher in T10.5. As concentrate intake increased, a lower milk urea level together with higher lactose and casein contents were observed (Table 2). These results may reflect a greater mammary availability of glucose and a better energy-protein balance in the rumen at T10.5. The non-fat solids content was significantly lower in T3.5 without differences between T7.0 and T10.5. The orthogonal contrasts showed linear increases for most of the analyzed parameters except for fat and TS concentrations that resulted similar between treatments.

\subsection{Dry Matter and Energy Intake}

Concentrate was thoroughly consumed by cows without refusals for any treatment. Pasture DM intake decreased (-20.7\%), while total DM and net energy for lactation $\left(\mathrm{NE}_{1}\right)$ increased $(+12.6 \%$ and $+20.7 \%$, respectively) with concentrate intake. On the other hand, conversion efficiency remained constant (Table 3).

These results suggest that the increase in milk production obtained with increasing levels of concentrate intake would be linked to a higher DM and energy intake. Substitution rate ( $\mathrm{kg}$ DM pasture $\mathrm{kg}$ DM concentrate ${ }^{-1}$ ) was similar between treatments with an average value of 0.58 .

Table 3. Dry matter and energy intake in grazing dairy cows supplemented with 3.5 (T3.5), 7.0 (T7.0) and 10.5 (T10.5) $\mathrm{kg} \mathrm{d}^{-1}$ of concentrate.

\begin{tabular}{|c|c|c|c|c|c|c|}
\hline \multirow{2}{*}{ Parameter } & \multicolumn{3}{|c|}{ Treatment $^{1}$} & \multirow{2}{*}{ SEM } & \multicolumn{2}{|c|}{$P<<^{2}$} \\
\hline & T3.5 & T7.0 & $\mathrm{T} 10.5$ & & Treat & Period \\
\hline \multicolumn{7}{|l|}{ Pasture intake } \\
\hline $\mathrm{DM}, \mathrm{kg} \mathrm{d}^{-1}$ & $17.96^{\mathrm{a}}$ & $16.07^{\mathrm{b}}$ & $14.24^{\mathrm{c}}$ & 0.18 & 0.01 & 0.01 \\
\hline $\mathrm{NE}_{1}^{3}, \mathrm{Mcal} \mathrm{d}^{-1}$ & $26.76^{\mathrm{a}}$ & $23.95^{\mathrm{b}}$ & $21.22^{\mathrm{c}}$ & 0.27 & 0.01 & 0.01 \\
\hline \multicolumn{7}{|l|}{ Total intake } \\
\hline $\mathrm{DM}, \mathrm{kg} \mathrm{d}^{-1}$ & $21.15^{\mathrm{c}}$ & $22.45^{\mathrm{b}}$ & $23.81^{\mathrm{a}}$ & 0.18 & 0.01 & 0.01 \\
\hline $\mathrm{NE}_{1}^{3}, \mathrm{Mcal} \mathrm{d}^{-1}$ & $32.95^{c}$ & $36.33^{\mathrm{b}}$ & $39.78^{\mathrm{a}}$ & 0.27 & 0.01 & 0.01 \\
\hline $\mathrm{GE}^{4}$, Mcal EN $\mathrm{L}^{-1}$ & $5.69^{c}$ & $7.91^{\mathrm{b}}$ & $9.93^{\mathrm{a}}$ & 0.05 & 0.01 & 0.01 \\
\hline \multicolumn{7}{|l|}{ Conversion efficiency } \\
\hline Milk, kg DM ${ }^{-1}$ & 1.48 & 1.52 & 1.52 & 0.06 & 0.36 & 0.04 \\
\hline Milk, Mcal EN ${ }_{\mathrm{L}}^{-1}$ & 0.95 & 0.94 & 0.91 & 0.04 & 0.13 & 0.04 \\
\hline $\mathrm{ECM} \mathrm{kg} \mathrm{MS}^{-1}$ & 1.27 & 1.33 & 1.29 & 0.06 & 0.25 & 0.02 \\
\hline ECM Mcal EN ${ }_{\mathrm{L}}^{-1}$ & 0.81 & 0.82 & 0.77 & 0.03 & 0.08 & 0.03 \\
\hline
\end{tabular}

${ }^{1}$ Values are expressed as least square means (LSMeans) and standard error of LSMeans (SEM). ${ }^{2}$ Effects of treatment (Treat) and period. ${ }^{3}$ Calculated using [22]. NEL values for the pasture and concentrate: 1.49 and $1.94 \mathrm{Mcal} \mathrm{kg} \mathrm{DM}^{-1}$, respectively. ${ }^{4}$ Energy provided by glucogenic precursors available from the rumen and small intestine [30]. ${ }^{\mathrm{a}, \mathrm{b}, \mathrm{c}}$ Within rows LSMeans with different superscripts differ (Tukey-Kramer test, $P<$ $0.05)$. 


\subsection{Changes in Body Weight and Body Condition Score}

BW loss (Table 4) and plasma NEFA concentration (Table 5) decreased with concentrate intake without changes in other variables associated with the variation of body reserves. Only cows in T10.5 gained BW (+157.6\% respect to T3.5).

\subsection{Plasma Concentration of Metabolites and Hormones}

Increased concentrate intake significantly enhanced plasma IGF-I concentration, a result consistent with the observed higher milk production (Table 2) and energy intake (Table 3). Circulating plasma levels of glucose, urea, insulin and GH were not affected (Table 5).

Table 4. Changes in body weight and body condition score in grazing dairy cows supplemented with 3.5 (T3.5), 7.0 (T7.0) and 10.5 (T10.5) $\mathrm{kg} \mathrm{d}^{-1}$ of concentrate.

\begin{tabular}{cccccccc}
\hline & \multicolumn{3}{c}{ Treatment $^{1}$} & & \multicolumn{3}{c}{$P<^{2}$} \\
\cline { 2 - 3 } Parameter & T3.5 & T7.0 & T10.5 & & Treat & Period \\
\hline BW, kg & & & & & & \\
Initial & $587.1^{\mathrm{a}}$ & $580.8^{\mathrm{b}}$ & $581.5^{\mathrm{b}}$ & 12.2 & 0.05 & 0.01 \\
Final & 580.5 & 580.7 & 585.4 & 12.8 & 0.08 & 0.01 \\
Change & $-6.6^{\mathrm{b}}$ & $-0.1^{\mathrm{ab}}$ & $3.8^{\mathrm{a}}$ & 2.5 & 0.02 & 0.01 \\
BCS, 1 to 5 & & & & & & \\
Initial & 2.50 & 2.46 & 2.43 & 0.06 & 0.18 & 0.02 \\
Final & 2.45 & 2.43 & 2.49 & 0.06 & 0.44 & 0.21 \\
Change & -0.05 & -0.03 & 0.06 & 0.04 & 0.13 & 0.02 \\
\hline
\end{tabular}

${ }^{1}$ Values are expressed as least square means (LSMeans) and standard error of LSMeans (SEM). ${ }^{2}$ Effects of treatment (Treat) and period. ${ }^{\mathrm{a}, \mathrm{b}}$ Within rows LSMeans with different superscripts differ (Tukey-Kramer test, $P<0.05)$.

Table 5. Plasma metabolites and hormones in grazing dairy cows supplemented with 3.5 (T3.5), 7.0 (T7.0) and 10.5 (T10.5) $\mathrm{kg} \mathrm{d}^{-1}$ of concentrate.

\begin{tabular}{|c|c|c|c|c|c|c|}
\hline \multirow{2}{*}{ Parameter } & \multicolumn{3}{|c|}{ Treatment $^{1}$} & \multirow{2}{*}{ SEM } & \multicolumn{2}{|c|}{$P<^{2}$} \\
\hline & T3.5 & T7.0 & $\mathrm{T} 10.5$ & & Treat & Period \\
\hline Glucose, $\mathrm{mmol} \mathrm{l}^{-1}$ & 3.53 & 3.41 & 3.46 & 0.05 & 0.10 & 0.01 \\
\hline Urea, $\mathrm{mmol} \mathrm{l}^{-1}$ & 7.47 & 7.42 & 7.21 & 0.21 & 0.37 & 0.01 \\
\hline NEFA, $\mu$ Eq $1^{-1}$ & $265.7^{\mathrm{a}}$ & $240.5^{\mathrm{ab}}$ & $227.6^{\mathrm{b}}$ & 12.4 & 0.02 & 0.01 \\
\hline $\mathrm{GH}, \mathrm{ng} \mathrm{ml}^{-1}$ & 3.89 & 3.97 & 3.75 & 0.36 & 0.90 & 0.56 \\
\hline Insulin, $\mathrm{ng} \mathrm{ml}^{-1}$ & 0.65 & 0.68 & 0.75 & 0.07 & 0.32 & 0.01 \\
\hline IGF-I, ng ml ${ }^{-1}$ & $113.1^{\mathrm{b}}$ & $128.9^{\mathrm{ab}}$ & $149.0^{\mathrm{a}}$ & 8.45 & 0.02 & 0.13 \\
\hline $\mathrm{GH} /$ Insulin ratio & 8.96 & 7.47 & 6.11 & 1.54 & 0.28 & 0.04 \\
\hline
\end{tabular}

${ }^{1}$ Values are expressed as least square means (LSMeans) and standard error of LSMeans (SEM). ${ }^{2}$ Effects of treatment (Treat) and period. ${ }^{\mathrm{a}, \mathrm{b}} \mathrm{W}$ ithin rows LSMeans with different superscripts differ (Tukey-Kramer test, $P<0.05)$. NEFA = non esterified fatty acids; $\mathrm{GH}=$ somatotrophin; IGF-I = somatomedin C. 


\subsection{Ruminal Environment and Pasture NDF Digestion}

The treatment $\times$ hour interaction was not significant for any variable of ruminal environment (Table 6). Acetate concentration and $\mathrm{pH}$ in T10.5 were lower than values from T3.5 and similar to T7.0 with no differences between T3.5 and T7.0. Molar proportion of propionate increased while proportion of acetate and the acetate:propionate ratio decreased as concentrate intake increased. Ruminal concentration of $\mathrm{NH}_{3}-\mathrm{N}$ tended $(p<0.07)$ to decrease as concentrate intake increased.

Kinetics parameters of NDF degradation were not affected except for the lag time that resulted lower $(p<0.05)$ in T7.0 and T10.5 with respect to T3.5 (Table 7).

In spite of the lower $\mathrm{pH}$ records observed as concentrate intake increased, effective pasture NDF degradability was unaffected.

Table 6. Parameters of rumen environment in grazing dairy cows supplemented with 3.5 (T3.5), 7.0 (7.0) and 10.5 (T10.5) $\mathrm{kg} \mathrm{d}^{-1}$ of concentrate.

\begin{tabular}{|c|c|c|c|c|c|c|c|}
\hline \multirow{2}{*}{ Parameter } & \multicolumn{3}{|c|}{ Treatment $^{1}$} & \multirow{2}{*}{ SEM } & \multicolumn{3}{|c|}{$P<<^{2}$} \\
\hline & T3.5 & T7.0 & $\mathrm{T} 10.5$ & & Treat & Hour & Treat ${ }^{*}$ Hour \\
\hline \multicolumn{8}{|l|}{ VFA } \\
\hline Total, mmol L $\mathrm{m}^{-1}$ & 75.3 & 67.5 & 66.3 & 3.17 & 0.29 & 0.01 & 0.96 \\
\hline Acetate, $\mathrm{mmol} \mathrm{L}^{-1}$ & $55.6^{\mathrm{a}}$ & $48.1^{\mathrm{ab}}$ & $45.7^{\mathrm{b}}$ & 2.20 & 0.01 & 0.02 & 0.94 \\
\hline Acetate, $\mathrm{mol} 100 \mathrm{~mol}^{-1}$ & $73.9^{\mathrm{a}}$ & $71.5^{\mathrm{b}}$ & $69.0^{c}$ & 0.34 & 0.01 & 0.04 & 0.36 \\
\hline Propionate, $\mathrm{mmol} \mathrm{L}^{-1}$ & 13.1 & 13.7 & 15.0 & 0.68 & 0.09 & 0.01 & 0.99 \\
\hline Propionate, mol $100 \mathrm{~mol}^{-1}$ & $17.4^{\mathrm{c}}$ & $20.2^{\mathrm{b}}$ & $22.5^{\mathrm{a}}$ & 0.25 & 0.01 & 0.10 & 0.63 \\
\hline Butyrate, $\mathrm{mmol} \mathrm{L}^{-1}$ & 6.6 & 5.7 & 5.6 & 0.47 & 0.39 & 0.01 & 0.79 \\
\hline Butyrate, mol $100 \mathrm{~mol}^{-1}$ & 8.7 & 8.3 & 8.4 & 0.20 & 0.46 & 0.05 & 0.13 \\
\hline Acetate:Propionate ratio & $4.25^{\mathrm{a}}$ & $3.55^{\mathrm{b}}$ & $3.08^{\mathrm{c}}$ & 0.06 & 0.01 & 0.05 & 0.60 \\
\hline $\mathrm{pH}$ & $6.20^{\mathrm{a}}$ & $6.02^{\mathrm{ab}}$ & $5.94^{\mathrm{b}}$ & 0.07 & 0.04 & 0.16 & 0.89 \\
\hline $\mathrm{NH}_{3}-\mathrm{N}, \mathrm{mg} \%$ & 41.62 & 35.87 & 35.04 & 2.14 & 0.07 & 0.01 & 0.93 \\
\hline
\end{tabular}

${ }^{1}$ Values are expressed as least square means (LSMeans) and standard error of LSMeans (SEM). ${ }^{2}$ Effects of treatment (Treat), hour and treat ${ }^{\star}$ hour interaction. ${ }^{\mathrm{a}, \mathrm{b}, \mathrm{c}}$ Within rows LSMeans with different superscripts differ (Tukey-Kramer test, $P<0.05)$. VFA = volatile fatty acids.

Table 7. Parameters of pasture NDF degradation in grazing dairy cows supplemented with 3.5 (T3.5), 7.0 (7.0) and 10.5 (T10.5) $\mathrm{kg} \mathrm{d}^{-1}$ of concentrate.

\begin{tabular}{|c|c|c|c|c|c|c|}
\hline \multirow{2}{*}{ Parameter } & \multicolumn{3}{|c|}{ Treatment $^{1}$} & \multirow{2}{*}{ SEM } & \multicolumn{2}{|c|}{$P<^{2}$} \\
\hline & T3.5 & T7.0 & $\mathrm{T} 10.5$ & & Treat & Period \\
\hline Digestible fraction, $\%$ & 66.38 & 57.83 & 55.96 & 3.44 & 0.28 & 0.26 \\
\hline Rate of digestion, $\%$ hour $^{-1}$ & 6.94 & 8.09 & 9.33 & 1.90 & 0.72 & 0.51 \\
\hline Lag time, hours & $3.64^{\mathrm{c}}$ & $2.40^{\mathrm{a}}$ & $3.07^{\mathrm{b}}$ & 0.45 & 0.01 & 0.01 \\
\hline \multicolumn{7}{|l|}{ Effective degradability } \\
\hline $\mathrm{Kp}^{3}=5 \%$ hour $^{-1}$ & 30.63 & 30.98 & 30.11 & 1.89 & 0.94 & 0.09 \\
\hline
\end{tabular}

${ }^{1}$ Values are expressed as least square means (LSMeans) and standard error of LSMeans (SEM). ${ }^{2}$ Treatment (Treat) and period effects. ${ }^{3}$ Rate of passage (kp) assumed according to [37]. a,b,c Within rows LSMeans with different superscripts differ (Tukey-Kramer test, $P<0.05$ ). 


\subsection{Milk Fatty Acid and Vitamins}

Milk fat levels of $\mathrm{C}_{10: 0}$ (caproic), $\mathrm{C}_{12: 0}$ (lauric) and $\mathrm{C}_{18: 2 n 6}$ (linoleic) resulted higher in T10.5 without differences between T3.5 and T7.0, whereas that of $\mathrm{C}_{18: 3 n 3}$ (linolenic) decreased and the $n-6 / n-3$ ratio was higher as concentrate intake increased (Table 8). The others milk FA remained unaffected.

Table 8. Milk fatty acid (FA) composition and antioxidant vitamins concentration in grazing dairy cows supplemented with 3.5 (T3.5), 7.0 (7.0) and 10.5 (T10.5) $\mathrm{kg} \mathrm{d}^{-1}$ of concentrate.

\begin{tabular}{|c|c|c|c|c|c|}
\hline \multirow{2}{*}{ FA $\left(g 100 g^{-1}\right)$} & \multicolumn{3}{|c|}{ Treatment $^{1}$} & \multirow{2}{*}{ SEM } & \multirow{2}{*}{$P<^{2}$} \\
\hline & T3.5 & T7.0 & $\mathrm{T} 10.5$ & & \\
\hline $\mathrm{C}_{4: 0}$ & 4.60 & 4.36 & 4.37 & 0.06 & 0.13 \\
\hline $\mathrm{C}_{6: 0}$ & 2.67 & 2.60 & 2.60 & 0.06 & 0.07 \\
\hline $\mathrm{C}_{8: 0}$ & 1.45 & 1.44 & 1.48 & 0.05 & 0.07 \\
\hline $\mathrm{C}_{10: 0}$ & $2.96^{\mathrm{b}}$ & $3.00^{\mathrm{b}}$ & $3.09^{\mathrm{a}}$ & 0.10 & 0.02 \\
\hline $\mathrm{C}_{10: 1}$ & 0.33 & 0.33 & 0.35 & 0.02 & 0.17 \\
\hline $\mathrm{C}_{12: 0}$ & $3.52^{\mathrm{b}}$ & $3.60^{\mathrm{ab}}$ & $3.71^{\mathrm{a}}$ & 0.11 & 0.04 \\
\hline $\mathrm{C}_{13: 0}$ & 0.12 & 0.11 & 0.12 & 0.005 & 0.50 \\
\hline $\mathrm{C}_{14: 0}$ & 12.17 & 12.12 & 12.38 & 0.19 & 0.65 \\
\hline $\mathrm{C}_{14: 1 \mathrm{lc}}$ & 0.94 & 0.96 & 1.02 & 0.03 & 0.35 \\
\hline $\mathrm{C}_{15: 0}$ & 1.37 & 1.26 & 1.26 & 0.03 & 0.15 \\
\hline $\mathrm{C}_{15 \text { iso }}$ & 0.26 & 0.28 & 0.25 & 0.01 & 0.34 \\
\hline $\mathrm{C}_{16: 0}$ & 28.36 & 27.47 & 27.47 & 0.61 & 0.27 \\
\hline $\mathrm{C}_{16: 1 \mathrm{c} 9}$ & 1.53 & 1.48 & 1.50 & 0.02 & 0.51 \\
\hline $\mathrm{C}_{17: 0}$ & 0.72 & 0.68 & 0.64 & 0.01 & 0.09 \\
\hline $\mathrm{C}_{18: 0}$ & 9.62 & 9.97 & 9.58 & 0.17 & 0.38 \\
\hline $\mathrm{C}_{18: 1+11}(\mathrm{VA})$ & 3.31 & 3.27 & 2.99 & 0.21 & 0.26 \\
\hline $\mathrm{C}_{18: 1 \mathrm{c} 9}$ & 16.79 & 17.49 & 17.71 & 0.24 & 0.21 \\
\hline $\mathrm{C}_{18: 2 \mathrm{n} 6}$ & $2.04^{\mathrm{b}}$ & $2.24^{\mathrm{b}}$ & $2.56^{\mathrm{a}}$ & 0.06 & 0.03 \\
\hline $\mathrm{C}_{18: 3 \mathrm{n} 3}$ & $1.30^{\mathrm{a}}$ & $1.07^{\mathrm{b}}$ & $0.93^{c}$ & 0.04 & 0.02 \\
\hline $\mathrm{CLA}_{\mathrm{cg} . \mathrm{t11}}(\mathrm{RA})$ & 1.18 & 1.16 & 1.15 & 0.08 & 0.75 \\
\hline $\mathrm{C}_{22}+\mathrm{C}_{20: 4 \mathrm{n} 6}+\mathrm{C}_{20: 3 \mathrm{n} 3}$ & 0.22 & 0.23 & 0.21 & 0.01 & 0.53 \\
\hline$\sum \mathrm{C}_{12: 0}$ to $\mathrm{C}_{16: 0}$ & 44.04 & 43.18 & 43.55 & 0.63 & 0.60 \\
\hline$n-6 / n-3$ ratio & $1.56^{\mathrm{c}}$ & $2.10^{\mathrm{b}}$ & $2.77^{\mathrm{a}}$ & 0.05 & 0.01 \\
\hline \multicolumn{6}{|c|}{ Antioxidant vitamins ( $\mu \mathrm{g} g$ milk fat $^{-1}$ ) } \\
\hline Retinol & 5.45 & 5.62 & 4.97 & 0.67 & 0.55 \\
\hline$\alpha$-tocoferol & 36.63 & 41.94 & 36.83 & 1.99 & 0.30 \\
\hline$\gamma$-tocoferol & 0.67 & 1.12 & 1.11 & 0.11 & 0.16 \\
\hline$\beta$-carotene & 4.73 & 7.12 & 5.99 & 0.41 & 0.07 \\
\hline
\end{tabular}

${ }^{1}$ Values are expressed as least square means (LSMeans) and standard error of LSMeans (SEM). ${ }^{2}$ Treatment effect. ${ }^{\mathrm{a}, \mathrm{b}, \mathrm{c}}$ Within rows means with different superscripts differ (Tukey-Kramer test, $P<0.05$ ). VA $=$ vaccenic acid. $\mathrm{RA}=$ rumenic acid. 
The hypercholesterolemic fraction of milk fat $\left(\mathrm{C}_{12: 0}\right.$ to $\mathrm{C}_{16: 0}$. $)$ remained unchanged when levels of concentrate intake increased. Linolenic $\left(\mathrm{C}_{18: 3 \mathrm{n} 3}\right)$ concentration was lowered and the $n-6: n-3$ ratio raised but it remained below the recommended values $(<4: 1)$ for human health. Antioxidant vitamin content of milk fat was not significantly altered in spite of the lower pasture DM intake (-21\%) between T3.5 and T10.5 (Table 8).

\section{Discussion}

\subsection{Milk Production and Composition}

The linear response in milk production observed in this trial (Table 2) was also reported by [11] in their review work for high-potential cows producing more than $28 \mathrm{~kg} \mathrm{day}^{-1}$ when concentrate intake ranged from 1.8 to $10 \mathrm{~kg} \mathrm{DM} \mathrm{cow}{ }^{-1}$ $\mathrm{day}^{-1}$. When pasture silage was the only forage source, an overall analysis of results obtained under controlled feed conditions in cows producing 27 to $30 \mathrm{~kg}$ milk day ${ }^{-1}$ showed that the highest response in milk output was obtained when glucogenic energy intake represented about $25 \%-30 \%$ of $\mathrm{NE}_{1}$ intake [30]. In the present trial, the T10.5 treatment represented the highest proportion of glucogenic energy absorbed from the diet ( $25 \%$ of $\mathrm{NE}_{1}$ intake), a value placed within the optimum range proposed by [30] contributing to explain the higher milk production observed in this treatment. The availability of glucogenic energy appears to have limited milk production in T3.5 and T7.0 treatments.

In grazing conditions, milk protein content is often increased after the intake of starchy concentrates [11] [46] probably linked to a higher availability of rumen propionate (the main glucogenic precursor) and microbial protein production which results in increased availability of amino acids in the small intestine. A linear increase in milk protein content $(+0.04 \%)$ per extra Mcal of glucogenic energy absorbed was reported by [30] in the range from 4 to $12 \mathrm{Mcal} \mathrm{d}^{-1}$. According to glucogenic energy intakes theoretically achieved in the present trial (Table 3), an increase in milk protein content would have been expected [30]. A trend $(P<0.08)$ was detected for a higher protein content in T10.5 (Table 2). It is likely that the absence of a significant increase in milk protein content has been masked by a dilution effect when milk production was increased. Milk protein yield linearly increased with concentrate intake (Table 2) as was reported by [13].

According to [11] when concentrate intake is increased in grazing dairy cows a decrease in milk fat content is expected a result that was not observed here (Table 2). When concentrate intake represents more than 50\% of total DM intake of grazing dairy cows reductions in milk fat content and yield are expected [47], but in this trial maximal concentrate intake represented only about $40 \%$ of total DM intake (Table 3). Milk fat content may also be reduced when dietary NDF content is low [48] owing to a decrease in ruminal $\mathrm{pH}$ values and acetate concentration, the main precursor of fatty acids synthesized de novo in the mammary gland. In this trial, ruminal $\mathrm{pH}$ values, concentration of acetate and 
the acetate/propionate ratio decreased as concentrate intake increased (Table 6) but milk fat content remained unaffected (Table 2). Dietary NDF content in T10.5 averaged $28 \%$ with $20.8 \%$ of NDF arising from forage. This NDF level was apparently sufficient to prevent a drop in milk fat content (Table 2). When NDF content is about $25 \%$ of total DM in the ration with $16 \%$ NDF arising from forage, milk fat content is not affected [22]. Milk fat yield instead resulted higher in T10.5 $\left(+110 \mathrm{~g} \mathrm{~d}^{-1}\right)$ compared to T3.5 (Table 2) as reported in [11].

Milk lactose content linearly increased with concentrate intake (Table 2), which would contribute to explain the linear increase in milk production observed. According to this result, previous studies under controlled feed conditions using pasture silage as forage showed that increasing availability of glucogenic precursors (mainly glucose) was a key factor to maximize lactose synthesis [30] [49] [50].

The lack of changes in 4\% FCM and ECM production when concentrate intake exceeded $28 \%$ of total DM intake (Table 2 ) was not apparently explained by substitution of pasture by concentrate because substitution rate was similar $(P>$ 0.05 ) between treatments ( 0.59 and 0.58 for T7.0 and T10.5, respectively) or by a less effective pasture NDF degradability (Table 7) as suggested by [51], or by a decrease in milk fat content (Table 2).

The increase of casein content and the trend to the lower milk urea nitrogen with gradual increases in concentrate intake (Table 2) was consistent with results obtained in previous studies [13] [52] suggesting that the intake of starchy concentrates improves nitrogen utilization. In the present study, the concentration of $\mathrm{NH}_{3}-\mathrm{N}$ in rumen tended to decrease $(P<0.07)$ with increasing levels of concentrate consumption (Table 6) which would contribute to explain the observed reduction in milk urea levels.

\subsection{Dry Matter and Energy Intake}

It was reported [11] that increasing concentrate consumption from 1.8 to $10.4 \mathrm{~kg}$ MS day ${ }^{-1}$ reduced pasture DM intake by $-1.9 \mathrm{~kg} \mathrm{day}^{-1}$ (range: -0.1 to $-4.4 \mathrm{~kg}$ day $^{-1}$ ) and increased total DM intake in $3.6 \mathrm{~kg} \mathrm{day}^{-1}$ (range: +1.0 to $+7.5 \mathrm{~kg}$ day $^{-1}$ ) compared with non supplemented pasture diets. According to these results pasture DM intake decreased $\left(-1.9\right.$ and $-3.7 \mathrm{~kg}$ day $\left.^{-1}\right)$ and total DM intake increased $\left(+1.3\right.$ and $\left.+2.7 \mathrm{~kg} \mathrm{day}^{-1}\right)$ in T7.0 vs. T3.5 and T10.5 vs. T3.5 respectively (Table 3). It was postulated that substitution rate often increases with increasing concentrate intake [48] but this general relationship is inconsistent for high yielding grazing cows [11] in agreement with results obtained in the present study (0.59 and $0.58 \mathrm{~kg}$ DM pasture $\mathrm{kg}$ DM concentrate ${ }^{-1}$ for T7.0 and T10.5, respectively). A higher substitution rate could be explained by negative associative effects at the ruminal level [53] coupled to reductions in ruminal $\mathrm{pH}$, activity or number of cellulolytic bacteria leading to a low rate of fiber digestion and pasture intake reduction [53]. In the present study, the increase in concentrate intake affected neither the degradability nor the rate of digestion of pasture NDF 
(Table 7) contributing to explain the lack of effect on substitution rate.

The estimated increase in $\mathrm{NE}_{\mathrm{L}}$ intake arising from concentrate (6.2 and 12.4 Mcal $\mathrm{d}^{-1}$ for T7.0 and T10.5, respectively) resulted higher than the decrease in $\mathrm{NE}_{\mathrm{L}}$ intake from pasture $\left(-2.8\right.$ and $-5.5 \mathrm{Mcal} \mathrm{d}^{-1}$ for T7.0 and T10.5, respectively) resulting in a higher total $\mathrm{NE}_{\mathrm{L}}$ intake (Table 3 ). This result suggest and additive effect after concentrate supplementation. The conversion efficiency of DM and $\mathrm{NE}_{\mathrm{L}}$ was similar between treatments (Table 3 ) in agreement with Wales (2005, cited by [54]), who suggested that the lack of response in conversion efficiency would be explained by the substitution rate. In the present study, the substitution rate resulted similar between treatments but it is worthy to note that in T3.5 cows apparently mobilized body reserves to sustain milk production which could have masked real differences in conversion efficiency.

\subsection{Body Parameters and Plasma Concentration of Metabolites and Hormones}

According with previous findings [12] [55], gains of BW and BCS increased with concentrate intake (Table 4). Although the Latin-square design may have disguised differences among treatments, short-term indicators of energy balance such as plasma NEFA concentration are useful to make inferences on changes in body reserves [52]. In the present study, circulating plasma NEFA levels decreased with concentrate intake suggesting a lower body fat mobilization. This results keeps well with the higher BW gain observed suggesting that part of the additional energy absorbed was used to restore body reserves.

Regardless the higher glucogenic energy theoretically absorbed when concentrate intake increased (Table 3) plasma glucose and insulin levels remained unchanged (Table 5) and circulating glucose levels remained within the reference ranges $\left(2.5\right.$ to $\left.4.16 \mathrm{mmol} \mathrm{l}^{-1}\right)$. The result keeps well with the observation that glycaemia is well regulated in ruminants [56]. Hepatic production of IGF-I is positively correlated with both, energy intake and plasma GH levels [57] and may contribute to enhance milk production [58]. In our experiment, cows consuming higher concentrate levels showed higher plasma IGF-I (but no GH) concentrations (Table 5) a result consistent with the higher energy intake and milk production. Concentrate intake tended $(P<0.07)$ to reduce ruminal $\mathrm{NH}_{3}-\mathrm{N}$ (Table 6) and decreased milk urea content (Table 2) without changes in plasma urea levels (Table 5) that remained in the lower portion of the normal range of 37 to $169 \mathrm{mg} \mathrm{dl}^{-1}$ proposed by [59].

\subsection{Ruminal Environment and Pasture NDF Digestion}

A lower ruminal $\mathrm{pH}$ is expected with increasing intake of starchy concentrates in grazing dairy cows [11] owing to a reduced ruminal buffer capacity, mastication and rumination activities, ruminal motility and modification of VFA production and composition [60]. Coincidently, in this study ruminal $\mathrm{pH}$ decreased with concentrate intake (Table 6). 
In line with the previously reported studies [13] [14] [52], supplementation with increasing levels of concentrate tended to decrease ruminal $\mathrm{NH}_{3}-\mathrm{N}$ (Table 6) a result that was consistent with the reduction in the content of milk urea (Table 2). The reduction in ruminal $\mathrm{NH}_{3}-\mathrm{N}$ could be explained by a better utilization of nitrogen by ruminal bacterias since the total CP intake $\left(5.20 \mathrm{~kg} \mathrm{day}^{-1}\right)$ resulted similar between treatments.

The lack of significant changes in total VFA concentration (Table 6) was consistent with that reported by [11]. As observed here (Table 6), supplementation with cereal grain based concentrates often increase the molar proportion of propionate and reduce the molar proportion of acetate altering the acetate:propionate ratio [11] [14] [61]. These changes were expected, since propionate is the main end product of starch fermentation.

It was reported that feeding corn-based concentrates does not affect the in situ pasture NDF digestion [11], but when the level of supplementation is greater than $8 \mathrm{~kg} \mathrm{DM} \mathrm{cow}^{-1} \mathrm{day}^{-1}$ pasture DM and NDF degradability may be affected indicating the existence of negative associative effects at ruminal level. In the present study, pasture NDF degradation was not affected (Table 7) even though maximum concentrate intake was $9.6 \mathrm{~kg} \mathrm{DM} \mathrm{cow}^{-1} \mathrm{day}^{-1}$ a result that was consistent with the lack of negative effects on milk fat content (Table 2). The mean ruminal $\mathrm{pH}$ observed (6.05, Table 6$)$ is compatible with adequate levels of forage digestion [62] and would contribute to explain the absence of treatment effect on the FDN pasture degradability.

\subsection{Nutritional Healthy Value of Milk}

The most remarkable feature in the present trial was that the consumption of concentrate up to $40 \%$ of total DM, did not affect either the total vaccenic acid (VA) or conjugated linoleic acid (CLA) content in milk. The average CLA concentrations ( $1.16 \mathrm{~g} / 100 \mathrm{~g}$ FA) obtained were similar to $1.2 \mathrm{~g}$ percent, as previously reported for dairy cows grazing alfalfa pastures [63]. This feature is remarkable because CLA (especially the C18:2 cis-9 trans-11 isomer) plays an important role in regulating plasma lipids and cardiovascular functions, reducing cancer incidence, as well as blocking tumor growth and metastasis from cancer breasts [64]. Indeed, VA (trans-11 18:1) is the main natural trans FA in milk and precursor of CLA in the mammary gland and other tissues by the activity of the delta-9 desaturase enzyme. VA may also have anticarcinogenic properties and can be metabolized by humans to bioactive CLA [65]. It has been previously reported that the supplementation with energy concentrates to grazing dairy cows reduced the VA and CLA contents in milk compared to the non-supplemented cows [66] [67] [68]. The effect could be explained by a decreased consumption of $\mathrm{C}_{18: 3}$ (mainly alpha linoleic acid) precursors of VA. When pasture intake decreased from $100 \%$ to $33 \%$ of total DMI of cows, milk CLA content decreased from 2.21 to $0.89 \mathrm{~g} / 100 \mathrm{~g}$ FA [69]. A positive association between the proportion of alfalfa pasture in the diet and the content of CLA and VA in milk also was 
reported by [63]. Apparently, even the lower contribution of pasture to total DMI in T10.5 (59.8\%) compared to T3.5 (84.9\%) was enough to retain milk bioactive FA concentration. As expected, increased levels of concentrate reduced milk content of $\mathrm{C}_{18: 3 n-3}$ and increased that of $\mathrm{C}_{18: 2 n-6}$ and the $n-6: / n-3$ ratio. Nevertheless, the ratio remained below the 4:1 recommended for a healthy diet [70] even in T10.5 (2.77). Similar results were previously reported [67] [68]. It is important to point out that the content of saturated FA like lauric $\left(\mathrm{C}_{12: 0}\right)$, myristic $\left(_{140}\right)$ and palmitic $\left(\mathrm{C}_{16: 0}\right)$ remained unaltered within the present trial especially because of their association with increased risk of heart disease [65] [71].

Antioxidant vitamins content was also not affected by concentrate feeding. Moreover the average concentrations of all-trans $\beta$-carotene and retinol in the present work were similar to those found by [72] in a system with extruded linseed supplementation $(5.35 \pm 0.34$ vs. $6.38 \pm 0.50$ and $5.95 \pm 1.20$ vs. $7.31 \pm 0.44$ $\mu \mathrm{g} \mathrm{g}{ }^{-1}$, respectively) but higher for $\alpha$-tocopherol (38.47 \pm 3.01 vs. $8.27 \pm 4.78 \mu \mathrm{g}$ $\mathrm{g}^{-1}$ ), probably due to the pasture feeding as demonstrated previously [28]. Therefore, its natural oxidative stability has shown to be not compromised for its further processing.

\section{Conclusion}

Increased levels of concentrate intake was an effective tool to improve milk yield in grazing dairy cows fed good quality alfalfa pastures without affecting pasture fiber digestion. Additive effects for DM and energy intakes were observed even when forage quality and quantity were non-limiting. Increased consumption of glucogenic energy failed to improve milk protein content but casein concentration and protein yield were enhanced. The increase in BW gain with increasing concentrate intake was compatible with the reduction of the circulating levels of NEFA and the reduction in the rumen acetate:propionate ratio but not with the absence of increases in plasma insulin concentration or decreases in the $\mathrm{GH} /$ insulin ratio, parameters that were not altered by supplementation levels. We have demonstrated for the first time that the increase on concentrate intake, up to $40 \%$ of total DM, did not affect the concentration of bioactive micronutrients in milk maintaining the healthy value of the milk produced.

\section{Acknowledgements}

This work was supported by the National Institute of Agricultural Technology (INTA). This Institute is a decentralized state agency with operational and financial autarchy, under the Ministry of Agroindustry of the Argentine Republic. This publication is part of the requirements to access to the academic degree of Doctor in Agricultural Sciences by the Mar del Plata National University, Argentina.

\section{References}

[1] Hills, J.L., Wales, W.J., Dunshea, F.R., Garcia, S.C. and Roche, J.R. (2015) Invited 
Review: An Evaluation of the Likely Effects of Individualized Feeding of Concentrate Supplements to Pasture-Based Dairy Cows. Journal of Dairy Science, 98, 1363-1401. https://doi.org/10.3168/jds.2014-8475

[2] Purvis, G., Downey, L., Beever, D., Doherty, M.L., Monahan, F.J., Sheridan, H. and McMahon, B.J. (2012) Development of a Sustainably-Competitive Agriculture, Agroecology and Strategies for Climate Change. Sustainable Agriculture Reviews, 8 , 35-65.

[3] Dillon, P., Hennessy, T., Shalloo, L., Thorne, F. and Horan, B. (2008) Future Outlook for the Irish Dairy Industry: A Study of International Competitiveness, Influence of International Trade Reform and Requirement for Change: Review. International Journal Dairy Technology, 61, 16-29. https://doi.org/10.1111/j.1471-0307.2008.00374.x

[4] Kolver, E.S. (2003) Nutritional Limitations to Increased Production on Pasture-Based Systems. Proceedings. Nutritional Society, 62, 291-300.

https://doi.org/10.1079/PNS2002200

[5] Kolver, E.S. and Muller, L.D. (1998) Performance and Nutrient Intake of High Producing Holstein Cows Consuming Pasture or a Total Mixed Ration. Journal of Dairy Science, 81, 1403-1411. https://doi.org/10.3168/jds.S0022-0302(98)75704-2

[6] Peyraud, J.L. and Delaby, L. (2005) Combining the Optimal Management of Grazing and the Performances of Dairy Cows: Issue and Tools. INRA Production Animale, 18, 231-240.

[7] Peyraud, J.L., Comeron, E.A., Wade, M.H. and Lemaire, G. (1996) The Effect of Daily Herbage Allowance, Herbage Mass and Animal Factors upon Herbage Intake by Grazing Dairy Cows. Annales de Zootechnie, 45, 201-217. https://doi.org/10.1051/animres:19960301

[8] Muller, L.D. and Fales, S.L. (1998) Supplementation of Cool-Season Grass Pastures for Dairy Cattle. In: Cherney, J.H. and Cherney, D.J.R., Eds., Grass for Dairy Cattle, CAB International, Oxon, 335-350.

[9] Delaby, L. and Peyraud, J.L. (1997) Influence of Concentrate Supplementation Strategy on Grazing Dairy Cow's Performance. In: Christie, B.R., Ed., Proceedings of the XVIII International Grassland Congress, Winnipeg, 137-138.

[10] Gagliostro, G.A. and Chilliard, Y. (1992) Protected Lipid Utilization in Dairy Cows Nutrition. II. Effects on Plasma Concentration of Metabolites and Hormones, Body Lipid Mobilization and Metabolic Activity of Adipose Tissue. Revista Argentina de Producción Animal, 12, 17-32.

[11] Bargo, F., Muller, L.D., Kolver, E.S. and Delahoy, J.E. (2003) Invited Review: Production and Digestion of Supplemented Dairy Cows on Pasture. Journal of Dairy Science, 86, 1-42. https://doi.org/10.3168/jds.S0022-0302(03)73581-4

[12] Delaby, L. and Peyraud, J.L. (2003) The Effect of Two Contrasting Grazing Managements and Level of Concentrate Supplementation on the Performance of Grazing Dairy Cows. Animal Research, 52, 437-460.

https://doi.org/10.1051/animres:2003030

[13] Reis, R.B. and Combs, D.K. (2000) Effects of Increasing Levels of Grain Supplementation on Rumen Environment and Lactation Performance of Dairy Cows Grazing Grass-Legume Pasture. Journal of Dairy Science, 83, 2888-2898. https://doi.org/10.3168/jds.S0022-0302(00)75189-7

[14] Leddin, C.M., Stockdale, C.R., Hill, J., Heard, J.W. and Doyle, P.T. (2010) Increasing Amounts of Crushed Wheat Fed with Persian Clover Herbage Reduced Ruminal 
$\mathrm{Ph}$ and Dietary Fibre Digestibility in Lactating Dairy Cows. Animal Production Science, 50, 837-846. https://doi.org/10.1071/AN09157

[15] Elgersma, A. (2015) Grazing Increases the Unsaturated Fatty Acid Concentration of Milk from Grass-Fed Cows: A Review of the Contributing Factors, Challenges and Future Perspectives. European Journal of Lipid Science and Technology, 117, 1345-1369. https://doi.org/10.1002/ejlt.201400469

[16] Comeron, E., Romero, L., Peyraud, J.L., Bruno, O. and Delaby, L. (1995) Effects of Herbage Allowance on Performances of Dairy Cows Grazing Alfalfa Swards. Annales de Zootechnie, 44, 368.

[17] Meijs, J.A.C., Walters, R.J.K. and Keen, A. (1982) Sward Methods. In: Herbage Intake Handbook, British Grassland Society Ed., 11-36.

[18] Komarek, A.R. (1993) An Improved Filtering Technique for the Analysis of Neutral Detergent Fiber and Acid Detergent Fiber Utilizing the Filter Bag Technique. Ankom Tech. Corp., Fairport, Publication No. 101, 1-10.

[19] AOAC (Association of Official Analytical Chemists) (1990) Official Methods of Analysis. 15th Edition, AOAC, Washington DC.

[20] AOAC (Association of Official Analytical Chemists) (1998) Official Methods of Analysis. 16th Edition, AOAC, Arlington.

[21] Tilley, J.M.A. and Terry, R.A. (1963) A Two-Stage Technique for in Vitro Digestion of Forage Crops. Journal British Grassland Society, 18, 104-111. https://doi.org/10.1111/j.1365-2494.1963.tb00335.x

[22] National Research Council (2001) Nutrient Requirements of Dairy Cattle. 7th Revision Edition, National Academy Press, Washington DC.

[23] Mcrae, J.E. and Armstrong, D.G. (1968) Enzyme Method for Determination of Alpha-Linked Glucose Polymers in Biological Materials. Journal Science Food Agriculture, 19, 578-581. https://doi.org/10.1002/jsfa.2740191006

[24] ISO 9622 IDF 141 (2013) Milk and Liquid Milk Products-Guidelines for the Application of Mid-Infrared Spectrometry.

[25] Gaines, W.L. and Davidson, F.A. (1923) Relation between Percentage of Fat Content and Yield of Milk. Univ. of Illinois Agri. Expt. Sta. Bull. 245.

[26] Tyrrell, H.F. and Reid, J.T. (1965) Prediction of the Energy Value of Cow's Milk. Journal of Dairy Science, 48, 1215-1223. https://doi.org/10.3168/jds.S0022-0302(65)88430-2

[27] Luna, P., Juarez, M. and De La Fuente, M.A. (2005) Validation of a Rapid Milk Fat Separation Method to Determine the Fatty Acid Profile by Gas Chromatography. Journal of Dairy Science, 88, 377-381. https://doi.org/10.3168/jds.S0022-0302(05)73021-6

[28] Rossetti, L., Langman, L., Grigioni, G.M., Biolatto, A., Sancho, A.M., Comerón, E. and Descalzo, A.M. (2010) Antioxidant Status and Odor Profile in Milk from Silage or Alfalfa-Fed Cows. Australian Journal Dairy Technology, 65, 3-9.

[29] Saliba, E.O.S., Faria, E.P., Rodriguez, N.M., Moreira, G.R., Sampaio, I.B.M., Saliba, J.S., Gonçalves, L.C., Borges, I. and Borges, A.L.C.C. (2015) Use of Infrared Spectroscopy to Estimate Fecal Output with Marker Lipe. International Journal Food Science Nutrition Diet, S4, 1-10.

[30] Rigout, S., Hurtaud, C., Lemosquet, S., Bach, A. and Rulquin, H. (2003) Lactational Effect of Propionic Acid and Duodenal Glucose in Dairy Cows. Journal of Dairy Science, 86, 243-253. https://doi.org/10.3168/jds.S0022-0302(03)73603-0 
[31] Huntington, G.B. (1997) Starch Utilization by Ruminants: From Basics to the Bunk. Journal of Animal Science, 75, 852-867. https://doi.org/10.2527/1997.753852x

[32] Wildman, E.E., Jones, G.M., Wagner, P.E., Boman, R.L., Troutt, H.F. and Lesch, T.N. (1982) A Dairy Cow Body Condition Scoring System and Its Relationship to Selected Production Characteristics. Journal of Dairy Science, 65, 495-501. https://doi.org/10.3168/jds.S0022-0302(82)82223-6

[33] Salado, E.E., Gagliostro, G.A., Becu-Villalobos, D. and Lacau-Mengido, I. (2004) Partial Replacement of Corn Grain by Hydrogenated Oil in Grazing Dairy Cows in Early Lactation. Journal of Dairy Science, 87, 1265-1278. https://doi.org/10.3168/jds.S0022-0302(04)73277-4

[34] Mehrez, A.Z. and Ørskov, E.R. (1977) A Study of the Artificial Fibre Bag Technique for Determining the Digestibility of Feeds in the Rumen. Journal of Agricultural Science Cambridge, 88, 645-650. https://doi.org/10.1017/S0021859600037321

[35] Mertens, D.R. and Loften, J.R. (1980) The Effect of Starch on Forage Fiber Digestion Kinetics in Vitro. Journal of Dairy Science, 63, 1437-1446. https://doi.org/10.3168/jds.S0022-0302(80)83101-8

[36] Fernández, H.H. (2004) A Simple Procedure for Estimate Useful Functions in Animal Production using Solver from Excel. Revista Argentina de Producción Animal, 24, 75-85.

[37] Van Vuuren, A.M., Krol-Kramer, F., Van der Lee, R.A. and Corbijn, H. (1992) Protein Digestion and Amino Acids in Dairy Cows Fed Fresh Lolium perenne with Different Nitrogen Contents. Journal of Dairy Science, 75, 2215-2225. https://doi.org/10.3168/jds.S0022-0302(92)77982-X

[38] Friggens, N.C., Oldham, J.D., Dewhurst, R.J. and Horgan, G. (1998) Proportions of Volatile Fatty Acids in Relation to the Chemical Composition of Feeds Based on Grass Silage. Journal of Dairy Science, 81, 1331-1344. https://doi.org/10.3168/jds.S0022-0302(98)75696-6

[39] SAS Institute Inc. (1999) SAS/STAT User's Guide (Release 8.0). SAS Institute, Cary.

[40] Vérité, R. and Journet, M. (1970) Effect of the Water Content of Grass and Dehydration at Low Temperature upon Its Feeding Value for Dairy Cows. Annales de Zootechnie, 19, 255-268. https://doi.org/10.1051/animres:19700302

[41] Mertens, D.R. (1994) Regulation of Forage Intake. In: Fahey, E. and Madison, G.G., Eds., Forage Quality, Evaluation and Utilization, American Society Agrononomic, Inc., Crop Science Society American, Soil Science Society American, Inc., Madison, 59-114.

[42] Minson, D.J. (1990) Forage in Ruminant Nutrition. Academic Press, Inc., Queensland.

[43] Baudracco, J., Lopez-Villalobos, N., Holmes, C.W. and MacDonald, K.A. (2010) Effects of Stocking Rate, Supplementation, Genotype and Their Interactions on Grazing Dairy Systems: A Review. New Zealand Journal of Agricultural Research, 53, 109-133. https://doi.org/10.1080/00288231003777665

[44] Leaver, J.D. (1985) Milk Production from Grazed Temperate Grassland. A Review. Journal of Dairy Research, 52, 313-344. https://doi.org/10.1017/S0022029900024201

[45] Romero, L.A., Comeron, E.A., Bruno, O.A. and Díaz, M.C. (1995) Effect of Herbage Allowance on Performances of Dairy Cows Grazing Alfalfa Swards. 1. Intake and Ingestive Behaviour. Revista Argentina de Producción Animal, 15, 623-626.

[46] Kellaway, R. and Harrington, T. (2004) Feeding Concentrates Supplements for Dairy Cows. Revised Edition, Landlinks Press, Collingwood. 
[47] Walker, G.P., Stockdale, C.R., Wales, W.J., Doyle, P.T. and Dellow, D.W. (2001) Effect of Level of Grain Supplementation on Milk Production Responses of Dairy Cows in Mid-Late Lactation When Grazing Irrigated Pastures High in Paspalum (Paspalum dilatatum Poir.). Australian Journal of Experimental Agriculture, 41, 1-11. https://doi.org/10.1071/EA00076

[48] Kellaway, R. and Porta, S. (1993) Feeding Concentrates Supplements for Dairy Cows. Dairy Research and Development Corporation, Melbourne.

[49] Rigout, S., Lemosquet, S., van Eys, J.E., Blum, J.W. and Rulquin, H. (2002) Duodenal Glucose Increases Glucose Fluxes and Lactose Synthesis in Grass-Silage Fed Dairy Cows. Journal of Dairy Science, 85, 595-606. https://doi.org/10.3168/jds.S0022-0302(02)74113-1

[50] Lemosquet, S., Rigout, S., Bach, A., Rulquin, H. and Blum, W. (2004) Glucose Metabolism in Lactating Cows in Response to Isoenergetic Infusions of Propionic Acid or Duodenal Glucose. Journal of Dairy Science, 87, 1767-1777. https://doi.org/10.3168/jds.S0022-0302(04)73332-9

[51] Garcia, S.C. and Fulkerson, W.J. (2005) Opportunities for Future Australian Dairy Systems: A Review. Australian Journal Experimental Agriculture, 45, 1041-1055. https://doi.org/10.1071/EA04143

[52] Bargo, F., Muller, L.D., Delahoy, J.E. and Cassidy, T.W. (2002) Milk Response to Concentrate Supplementation of High Producing Dairy Cows Grazing at Two Pasture Allowances. Journal of Dairy Science, 85, 1777-1792. https://doi.org/10.3168/jds.S0022-0302(02)74252-5

[53] Dixon, R.M. and Stockdale, C.R. (1999) Associative Effects between Forages and Grains: Consequences for Feed Utilization. Australian Journal of Agricultural Research, 50, 757-773. https://doi.org/10.1071/AR98165

[54] Beever, D.E. and Doyle, P.T. (2007) Feed Conversion Efficiency as a Key Determinant of Dairy Herd Performance: A Review. Australian Journal Experimental Agriculture, 47, 645-657. https://doi.org/10.1071/EA06048

[55] McEvoy, M., Kennedy, E., Murphy, J.P., Boland, T.M., Delaby, L. and O’Donovan, M. (2008) The Effect of Herbage Allowance and Concentrate Supplementation on Milk Production Performance and Dry Matter Intake of Spring-Calving Dairy Cows in Early Lactation. Journal of Dairy Science, 91, 1258-1269. https://doi.org/10.3168/jds.2007-0710

[56] Noro, M., Vargas, V., Pulido, R.G. and Wittwer, F. (2006) Effects of Two Type of Concentrate on Energy and Protein Blood Metabolites in Grazing Dairy Cows during Spring. Archivos de Medicina Veterinaria, 38, 227-232.

[57] McGuire, M.A., Dwyer, D.A., Bauman, D.E. and Smith, D.F. (1998) Insulin-Like Growth Factors in Plasma and Afferent Mammary Lymph of Lactating Cows Deprived of Feed or Treated with Bovine Somatotropin. Journal of Dairy Science, 81, 950-957. https://doi.org/10.3168/jds.S0022-0302(98)75655-3

[58] Cohick, W.S. (1998) Role of the Insulin-Like Growth Factors and Their Binding Proteins in Lactation. Journal of Dairy Science, 81, 1769-1777. https://doi.org/10.3168/jds.S0022-0302(98)75746-7

[59] Radostits, O.M., Gay, C.C., Hinchcliff, K.W. and Constable, P.D. (2006) Veterinary Medicine. 10th Editions, Saunders Elsevier, 2162-2165.

[60] Kolver, E.S. and de Veth, M.J. (2002) Prediction of Ruminal pH from Pasture-Based Diets. Journal of Dairy Science, 85, 1255-1266. https://doi.org/10.3168/jds.S0022-0302(02)74190-8 
[61] Wales, W.J. and Doyle, P.T. (2003) Effect of Grain and Straw Supplementation on Marginal Milk-Production Responses and Rumen Fermentation of Cows Grazing Highly Digestible Subterranean Clover Pasture. Australian Journal of Experimental Agriculture, 43, 467-474. https://doi.org/10.1071/EA02083

[62] De Veth, M.J. and Kolver, E.S. (2001) Digestion of Ryegrass Pasture in Response to Change in $\mathrm{pH}$ in Continuous Culture. Journal of Dairy Science, 84, 1449-1457. https://doi.org/10.3168/jds.S0022-0302(01)70178-6

[63] Castillo, A.R., Taverna, M.A., Páez, R.R., Cuatrin, A., Colombatto, D., Bargo, F., García, M.S., García, P.T., Chavez, M., Beaulieu, A.D. and Drackley, J.K. (2006) Fatty Acid Composition of Milk from Dairy Cows Fed Fresh Alfalfa Based Diets. Animal Feed Science and Technology, 131, 241-254.

[64] Parodi, P.W. (1999) Conjugated Linoleic Acid and Other Anticarcinogenic Agents of Bovine Milk Fat. Journal of Dairy Science, 82, 1339-1349. https://doi.org/10.3168/jds.S0022-0302(99)75358-0

[65] Stanton, C., Murphy, J., McGrath, E. and Devery, R. (2003) Animal Feeding Strategies for Conjugates Linoleic Acid Enrichment of Milk. In: Sebedio, J.L., Christie, W.W. and Adloff, R., Eds., Advances in Conjugated Linoleic Acid in Food, AOCS Press, Champaign, Vol. 2, 123-145.

[66] Stockdale, C.R., Walker, G.P., Wales, W.J., Dalley, D.E., Birkett, A., Shen, Z. and Doyle, P.T. (2003) Influence of Pasture and Concentrates in the Diet of Grazing Dairy Cows on the Fatty Acid Composition of Milk. Journal of Dairy Research, 70, 267-276. https://doi.org/10.1017/S0022029903006009

[67] Wijesundera, C., Shen, Z., Wales, W.J. and Dalley, D.E. (2003) Effect of Cereal Grain and Fibre Supplements on the Fatty Acid Composition of Milk Fat of Grazing Dairy Cows in Early Lactation. Journal of Dairy Research, 70, 257-265. https://doi.org/10.1017/S0022029903006241

[68] Bargo, F., Delahoy, J.E., Schroeder, G.F. and Muller, L.D. (2006) Milk Fatty Acid Composition of Dairy Cows Grazing at Two Pasture Allowances and Supplemented with Different Levels and Sources of Concentrate. Animal Feed Science and Technology, 125, 17-31.

[69] Dhiman, T.R., Anand, G.R., Satter, L.D. and Tariza, M.W. (1999) Conjugated Linoleic Acid Content of Milk from Cows Fed Different Diets. Journal of Dairy Science, 82, 2146-2156. https://doi.org/10.3168/jds.S0022-0302(99)75458-5

[70] Simopoulos, A.P. (2004) Omega-3 Essential Fatty Acid Ratio and Chronic Diseases. Food Reviews International, 20, 77-90. https://doi.org/10.1081/FRI-120028831

[71] Chilliard, Y. and Ferlay, A. (2004) Dietary Lipids and Forages Interactions on Cows and Goat Milk Acid Composition and Sensory Properties. Reproduction Nutrition Development, 44, 467-492. https://doi.org/10.1051/rnd:2004052

[72] Lerch, S., Ferlay, A., Graulet, B., Cirié, C., Verdier-metz, I., Montel, M.C., Chilliard, Y. and Martin, B. (2015) Extruded Linseeds, Vitamin E and Plant Extracts in Corn Silage-Based Diets of Dairy Cows: Effects on Sensory Properties of Raw Milk and Uncooked Pressed Cheese. International Dairy Journal, 51, 65-74. 